\title{
Twenty Three Years Reform in Indonesia and Unsolved Law Supremacy
}

\author{
Indriya Fathni $^{1} \quad$ M. Valiant Arsi Nugraha ${ }^{2} \quad$ M. Al-Haadi Nugraha ${ }^{3} \quad$ Johni Najwan $^{4}$
}

\begin{abstract}
As a modern country, Indonesia's constitution law has firmly stipulated that one of the characteristics of the Indonesian governmental system follows the principle of state law not absolute state of power. Based on this constitutional certainty, the government has a limited power and is not allowed to act cruelly or unlawfully. This principle has to be reflected in the practice of state government. In other words, in the practice of Indonesian state government, law must control the power but not in the other way round where the law is controlled by the power. However, in the real situation of state governing, it has often been found that both law and power do not run in the same path way, whereas the power tends to be dominant and the law is subordinated. Ideally, the power should go in line with the law. The problem now is to what extent the law can control the power, while at the same time, the law is the product of the authorized government. To answer this question, there should be an ideal solution in which a product of law should always control the governing power although it is a product of the ruling power or government.
\end{abstract}

Keywords: Reform in Indonesia, twenty three years, unsolved law supremacy.

DOI: $10.7176 / \mathrm{JLPG} / 105-13$

Publication date: January $31^{\text {st }} 2021$

\section{INTRODUCTION}

Conflict between law and power is a common phenomenon in the history of Indonesian national politics. The ideal condition is that both should play an important role in a state country and interact harmoniously. However, this ideal situation does not happen as expected and is difficult to be implementedand this has become a very long way of the state history which has been very costly and requires too much sacrifice.

It has been about twenty three years ago exactly on 21 May 1998, a big tragedy in the country of the Republic of Indonesia our beloved country, where something what we are familiar with "reform" has happened. It was a very important moment where the New Order under the control of president Soeharto collapsed and this order has been replaced by the Reform Order. ${ }^{5}$ This is true evidence where the harmony between law and power has been conflicting in the history of a country of Indonesia.

From the context of this tragedy, it is apparent that some problems regarding law and power gain their urgency so that any issues concerning the increasing power of the state can be seen as crucial and implicative particularly if it is seen from the perspectives of state law and the importance of democracy.

It is crucial because the power of the state plays a very important role that can be used as an indication of the harmonious relationship among basic elements of the state operations. It is implicative because this phenomenon is often seen as a factor which encourages the cases of oppressiveness and otoritarianitas (dictatorial) within the country life encounters. The discussion about this matter seems to be essential (though it might have been too late). This may happen because there have been many speculations that "law without power is unforceful, while power without law turns to be dictatorial".

In practice, it is often found that power and law do not run in the same line, where the power is more dominant while the law is often subordinated. Ideally, the power or authority should be operated based on law. The problem now is that how far the law can control the power, even though the law is a product of the authorized power or government? To answer this question, there should be an ideal solution in which the law should control the power, although the law itself is made by the power (government).

To answer this problem, this paper aims to analyze and criticize this phenomenon comprehensively from multi-perspectives. It is hoped that the findings will provide positive feedback for the government in their attempts to strengthen the supremacy of law in Indonesia which has been running for twenty three years.

\footnotetext{
${ }^{1}$ The author is a Lecturer at the Faculty of Law and a Student in the Law Doctoral Program at the Postgraduate Program at Jambi University. ${ }^{2}$ The author is a Lecturer at the Faculty of Law and a Student in the Law Doctoral Program at the Postgraduate Program at Jambi University. ${ }^{3}$ The author is a student of the Postgraduate Program in Law, Jambi University.

${ }^{4}$ The author correspondent is a lecturer and professor of comparative law at the Doctor of Law Program in the Graduate Program of Jambi University.

${ }^{5}$ Conceptually, especially in the sociological perspective, the explanation about the meaning of reform cannot be separable from the concept of "evolution" and "revolution", because its position lies between social evolution and revolution dichotomies. In other words, reformation is located on a position in the continuum line of social evolution and revolution.
} 


\section{LAW AND POWER BETWEEN DAS SOLLEN AND DAS SEIN}

In fact, views about the connection between law and power are not single. Among idealists who perceive the law as das sollen and empirical experts ${ }^{1}$ who see the law as das sein provide different views. However, the observers of both perceptions agree that "ideally, law is more powerful and dominant than the authorized power or government".

Consequently, a theory offered by Roscoe Pound (1870-1964) states "law as a tool of social engineering,"2 can be seen as an important position where law or legal system should control all life practices including the political life. However, when we refer to the view from Von Savigny which confirms that "law changes if the people change," 3 we should perceive this as a phenomenon where the law can be adjusted according to the social needs, meaning that in fact law can be affected by other external factors including political systems in a country. ${ }^{4}$

Empirical practices in the real life situations have shown that there have been so many law implementations (legal systems) without strong authorities just because the power of law is less forceful that the power of political system, ${ }^{5}$ so that all that can be seen is not only law materials which have been contaminated by the configuration of the power, but also the supremacy of the law is often interfered by the authority making law unforceful or ignored. Based on this condition, then the theory of "law as a product of political power" came up.

From this paradox, those who try to analyze the law can see at least two models or frameworks concerning the connection between law and power. They are: (1) law determines or affects the power; this belongs to the principle of das sollen; and (2) law is affected or determined, or even controlled by politics as often seen in the practice of das sein.

There is no need to compare which one is better than the other, as we believe that many theories often just portrait something which is happening continuously, thus the truth value of the theories depend on the basic framework and assumptions used by the analysts. Hence, it all depends on who will use the theory. Ultimately, it has often been heard that the theories are made based on the abstraction of the empirical study.

Ideally, both law and power should support each other. This means that law must be implemented and strengthened by the authority so that it becomes forceful and effective; on the other hand, the authority must be ruled based on the principles of law not on dictatorial principles. In this context, we should understand a law principle that "law without authority is nothing and authority without law is dictatorship".

However, something ideal does not always happen realistically, thus it has frequently been seen that the authority is above the law. Hence, L. J. Van Apeldoorn notes that there are at least four characters which follow a principle that the law is identical with the power; they are: ${ }^{6}$

1. The Sophistism, (in Greece) who believe that "Fairness or justice is just useful for those who are strong in position"

2. The Lasalleism, who state that "A constitution of a country is not the real one", but it is just a piece of paper and connected to real authority.

3. The Gumplowicsism, who claim that "the law is made based on vanquish of the strong authority towards the weak one". Thus, the law is a defined concept proposed by the strong authority to strengthen their power.

4. Some of the Positivism believe that compartment to the law obedience towards the law can be seen as a loyalty of the weak to the strong wants. So that the law just belongs to the strong (forceful) authority or power government.

Furthermore, L.J. Van Apeldoorn notes his views towards law and power as follows: ${ }^{7}$

1. Law is a part of power which can be connected to the strength of both inward or physical power, but the authority or power that are needed to strengthen the law should support the law so that the material of law cannot be seen as something real or essential.

\footnotetext{
${ }^{1}$ In the history of Western philosophy, in the past few centuries, there was an empirical movementthat is a philosophical group which views that experience can be seen as an appropriate way of gaining a truth value. In other words, empirical evidence is the only one source of the truth value. This movement was pioneered by: John Locke (1632-1714) and David Hume (1711-1776). See R. Poedjawinata, Logic Philosophy of Thinking, Jakarta: Rineka Cipta, 2019, p. 57.

${ }^{2}$ To fulfil its function as that instrument, thus Roscoe Pound (1876-1964) proposed some categorizations based on interests that need to be protected by law, they are: public interest; social interest; and private interest. Compare with Darji Darmodiharjo and Shidarta, Principples of Legal Philosophy, Revised Edition, Jakarta: Gramedia, 2019, p. 131.

${ }^{3}$ Compare with Philipe Nonet \& Philip Seznick. Law and Society in Transition: Toward Responsive Law. New York: Harper and Row, 2019, p. 21 .

${ }^{4}$ Until today, in England and in other commonwealth countries, there are still "statute law" that is a law made by the government and "common law" that is law which is not made by the government. Indonesia adopts living law along with constitution as a positive law. So, there is a law outside the constitution. In other words the constitution is just a part of law. Compare with L. J. van Apeldoorn, Introduction to The Science of Law. Jakarta: Pradnya Pramita, 2019, p. 15.

${ }^{5}$ Compare with the opinion from Lawrence Meir Friedman regarding three factors of law/legal system which determines law enforcement (there elements of legal system), they are: legal structure, legal substance, and legal culture. See Lawrence Meir Friedman, The legal System: A Social Science Perspective. New York: Russel Sage Foundation. 2019, pp. 14-20.

${ }^{6}$ L. J. van Apeldoorn, Op. Cit., pp. 57-71.

${ }^{7}$ Ibid
} 
2. The substance of law is identical with social power so that if there are certainties made based on threats and power, it can be said that they are actually not law, but something which weakens or ignores the law.

3. The law as part of power is defined as something which avoids the force of the material power so that any violations and forces are against law and thus should be made obedient to the law.

The above views show that any answers to the questions of the connection between law and power vary according to which theoretical frameworks are used. All the views in this article are used as the basis in analyzing or criticizing the practice of law and power in Indonesia, especially in the New Order era government who were ruling for about 32 years and the Reform era which has been running for about 17 years.

\section{LAW AND POWER}

As a modern country, the Indonesian Constitution has strongly described that one of the characteristics of the Indonesian governmental system complies with law based state or nation not power based state or nation ${ }^{1}$. Based on this stipulated statement, the ruling government has a limited power or authority and is not allowed to act unlawfully. These principles should be reflected in every practice of the governmental actions and regulations. This means that law should control the authority or power and not vice versa where the law is controlled by the power (government). In this context, the question is why the power should be controlled. The answer is very simple indeed: because according to Lord Acton (1834-1902) "power tends to corrupt and absolute power corrupts absolutely". Therefore, in order for the power not to be misused, there must be a law to control it.

In addition, law (constitution) is made to limit the authority of the power of a country. The word authority here means power, the power of the state, which has now been discussed a lot by young political experts, confirming that the power is identical with politics. Because both are regarded as identical, meaning at least that all political activities or practices are actually meant to gain power, thus there is an analog for this, that is politics tend to corrupt.

Consequently, in order for the power not to be uncontrolled and misused, law must be made to control that power, in other words, law must be supreme for the sake of limiting the power ${ }^{2}$. If the law is not supreme, as ever pointed out by Niccolo Machiavelli (1469-1527), which was very popular with "het doelheilight de mid delen", claiming that one could do whatever they want to achieve their goals. Hence, any political practices and aims with intended means of regulations should respect laws.

One thing that is hard to deny is the fact that no matter how tight the law is, with any intended political will and regulation, and any ethical act, most often, the law is unforceful when dealing with power because the law cannot control the power. This situation should never happen in the post era of reform, and this still happens, this will destroy the principles of law which have been stipulated in the concept of state laws in Indonesia.

Overall, in order for the law to be strengthened and supported, and in order to reach the ideal of state law and people power, and to encourage what has been declared by the reformists' aims and agenda, the government should act ideally according to the stipulated rules and law, thus the certainty of law and fairness can be applicable to all people. Shortly, in every practice of state, all certainties and regulations or laws must be respected and strongly implemented by the government.

In a state law like Indonesia, the law should not stand alone on one side, whereas on the other side, the power seems to disobey or confront to the law. This is, of course, not in line with principles of law which are stipulated on the Indonesian Constitution Law of 1945 (UUD 45). Thus, all commitments that have been stated during the reform period should always be respected and implemented in all state operations, so that the principle of rule of law can be implemented, not rule of power instead.

\section{REFORM AND UNSOLVED LAW SUPREMACY}

The spirit of proposing the reform era which was blasted since about twenty two (17) years ago, in principle is: "to propose law supremacy in Indonesia."” This is because the New Order government as a political system which ruled the country, has given a lesson that "the power is all above the law, so that there was no justice for people, and that was turning to a great chaos because the emerged stability of the state was artificial.

Another thing was that, the ending period of the New Order, according to a few analysts, happened because of instability of the state economy, politics, and governance. Some views from analysts regarding the crisis focused on governance aspect such as corruption, collusion, and nepotism, including some cases of law disobedience. Many people believed during that time governance reform was one of the best solution to solve the crisis of multi-

\footnotetext{
${ }^{1}$ See Chapter 1 article (3) Indonesia 1945 Constitution the $3^{\text {rd }}$ Revision.

${ }^{2}$ In general, law has a mission to run several functions, such as: dispute resolution, punishment and legitimation. See Achmad Ali, Deterioration of Law in Indonesia: Causes and Solutions, Ghalia Indonesia, Jakarta, 2019, pp 23-24.

${ }^{3}$ At least there were six requirements for the Reformation at that period, they are: (1) Amendment of 1945 Constitution, (2) Eradication of double function of Indonesian National Armed Force or Military Force (ABRI), (3) Law Enforcement, Human Rights and eradication of Collusion, Corruption, and Nepotism, (4) Regional Autonomy, (5) Freedom of Press Release, and (6) The Foster of Democratized life.
} 
dimension that has long been happening during the era of the New Order. According to Teten Masduki's concept of good governance can be defined as as "the concept of clean government, this all happens a strong demand from the people to go back to the system of people power (democracy) as the government was no longer effective during that period on the other side." 1

Shortly, the most recent world development or globalization era, the country will require a new system of maintaining economical power, politics, and administration, to govern the state in a transparent, participative, effective, fair way, confirming all people needs under the frame of "rule of the law".

The clean government is not enough, more ever for the future, where all public sectors tend to be mandated to private enterprises. As a result, the eradication of corruption should become the government priority. At this moment people have lost their trust the government and the cannot tolerate any divergences of some elites for their own sakes and benefits through controlling the majority of economic sectors but ignoring the destruction of the environment, as well as, showing bad public services and unforceful law empowerment in Indonesia. ${ }^{2}$

Until present, the issues of law supremacy and democracy in Indonesia have been often subject to political debates and discussions. Although the reform supporters have claimed their commitment to govern the country based on constitution and law. Not like what happened during the era of New Order, where some the rules and regulations have been disobeyed, the cases of corruption, collusion, and nepotism were everywhere, this all happened just because they did not comply with the needs of the elite government. Even, according to Boediono, the vice president of Indonesia, in his speech at UIN Syarif Hidayatullah Jakarta, on 23 December 2010, as quoted by Komarudin Hidayat:" "At this moment, there are two traps which are confronting the agenda of democracy development, they are; dis-functionality and degeneration of democracy". Indonesia, according to Boediono lies on the later (degeneration of democracy) as the commitment from political elites to foster a healthy and clean state remains very weak. If this continues to happen, as predicted by Boediono, the tragedy of France Revolution on the $18^{\text {th }}$ century which kill many smart people in France can happen in Indonesia.

Based on the problems regarding law supremacy in Indonesia, the core question is, "Why is it difficult to implement law supremacy in Indonesia?". In order for the law to function on the right dimension, according to Soerjono Soekanto, there are at least four factors that need to be made balanced: ${ }^{4}$

1. The law or the regulation itself.

It is possible that there has been a conflict between the regulations and certain life sectors in the country. Another possibility is that there has been a conflict between the regulations and undocumented law or traditional law. Sometime, there is also a conflict between documented and undocumented laws or regulations, and so on.

2. The mental state of the law officials.

Law officials include: judges/juries; police; executive lawyers; defend lawyers; prisoners' guards; and so on. Although the regulations are alright, but the mental state of the official remains fraud, there will be a trouble in attempting a clean law implementation system.

3. Facilities used to support law implementation.

If all regulations are already good as well as the mental state of the officials, but the facilities are inadequate, thus, the clean law implementation will not run well as expected.

4. The awareness and obedience of the society.

The above four factors are interconnected each other and function as the main variable in the law supremacy system. When all the factors are analyzed carefully, thus we can point out any aspects which affect the system of law implementation in Indonesia. Some of these aspects include: 'raw input', 'instrumental input', or 'environmental input', whether stands on itself or being interconnected from one to another.

\section{CONCLUSION}

If a conclusion needs to be provided, thus it can be summed up that: at this moment, Indonesia is in a condition where law supremacy does not yet run effectively and this is all caused by the ineffectiveness or undemocratization of political system. The weakening of law supremacy in Indonesia which is affected by the monopoly (un-democratization) of political system is understandable. This is because law and democracy are just like "two sides of the coin". In other words, if democracy is not running, thus the law cannot either function well to control the power.

\section{RECOMMENDATION}

In a country of the Republic of Indonesia, which is based on law, the law should be seen as rules of life to achieve the truth, justice, and orderliness. Ideally, law and power, at least, should go in line and support each other, meaning

\footnotetext{
${ }^{1}$ Teten Masduki, Corruption and Reform Good Governance. Kompas 15 April 2002.

${ }^{2}$ Compare with Teten Masduki. Ibid.

${ }^{3}$ Read Komarudin Hidayat, "Degeneration of Democracy", Kompas, 5 January 2011

${ }^{4}$ Soerjono Soekanto, Sociological Theory, About Personal in Society, Jakarta: Ghalia Indonesia, 2019, pp 83-84.
} 
that law should be strengthened through power so that it becomes more forceful and effective, and on the other hand, the power or authority should run based on principles of law not on dictatorship. If during the government before the era of reform, politics and economy became the main goals, thus in the era of post reform, law enforcement should be the main basis of the governmental system. This is because, to foster the country of Indonesia with justice, fair, welfare, unity, and people powered, the truth value that is used must be based on law principles.

\section{REFERENCES}

Ali, Achmad. 2018. Reveals the Legal Theory and Judicialprudence Including Legisprudence. Jakarta: Kencana. Ali, Achmad. 2019. Deterioration of Law in Indonesia: Causes and Solutions. Jakarta: Ghalia Indonesia.

Bernard L. Tanya et al. 2019. Legal Theory: Strategy orderly People Across Space and Generation. Yogyakarta: Genta Publishing.

Darmodiharjo, Darji and Shidarta. 2019. Principples of Legal Philosophy. Revised Edition, Jakarta: Gramedia.

Friedman, Lawrence Meir. 2018. The Legal System: A Social Science Perspective. New York: Russel Sage Foundation.

Komarudin Hidayat. 2011. Degeneration of Democracy, Kompas, 5 January 2011.

Liddle, R. William. 2018. Participation and Political Parties: Indonesia at The Beginning of the New Order. Jakarta: Grafiti.

Moh. Mahfud MD. 2018. The Constitution and The Law in Controversy Issue. Jakarta: Raja Grafindo Persada. Nonet, Phillipe \& Seznick, Phillipe. 2018. Law and Society in Transition: Toward Responsive Law. New York: Harper and Row.

Pound, Roscoe. 2018. Interpretations of Legal History. New York: The Macmillan Company.

Pound, Roscoe. 2019. An Introduction to the Philosophy of Law. New York: The Macmillan Company. Poedjawinata, R. 2019. Logic Philosophy of Thinking. Jakarta: Rineka Cipta.

Soekanto, Soerjono. 2019. Sociological Theory, About Personal in Society. Jakarta: Ghalia Indonesia.

Teten Masduki. 2002. Corruption and Reform Good Governance. Kompas 15 April 2002.

Van Apeldoorn, L. J. 2018. Inleiding tot de Studie Van Het Nederlandse Recht. Jakarta: Pradnya Paramita. 